\title{
MODEL PARTISIPASI MASYARAKAT MOI DALAM PELAKSANAAN PENDIDIKAN ADAT KAMBIK \\ (Studi Kasus Tentang Kelangsungan Pendidikan Kambik Di Suku Moi Kampung Maladofok Kabupaten Sorong).
}

\author{
Yuliana $\mathrm{A}^{1}$, Heriyanti ${ }^{2}$ \\ ${ }^{1,2}$ Fakultas Ilmu Keguruan dan Ilmu Pendidikan, Universitas Muhammadiyah Sorong.
}

\begin{abstract}
ABSTRAC
The purpose of this study was to reveal the Participation of the Moi Community in Kambik Education (Indigenous Education) in Maladofok Village, Sorong Regency. Kambik education is a Moi tribal education system in Sorong, West Papua. Kambik education (Moi tribal customary education) learns about leadership, learns the customs of the Moi tribe, traditional medicine, and understands human existence. Various problems began to emerge in the life of the state, the demand for revival and reviving the values of local wisdom into an alternative. So it is important in this research, the researcher raises two issues that have been formulated in the question. First: What is the participation of the Moi community in the Kambik education process ?, and Second; to what extent are the values taught in Kambik's education in social life? This question is important to be formulated as the power of data which then becomes a reference in education policy that raises local potential. The research uses a qualitative approach. Researchers conducted in-depth interviews at the research location, more points than the ethnographic method itself is that researchers conduct research and also get meaningful education from the lives of local people. The results of this study are to encourage the acceleration of development in Sorong Regency. Because in addition to the academic interests, the Moi tribe Kambik (traditional education) education is a new alternative form of humanity awareness in the Moi tribe of Sorong Regency. The results of this study could be a recommendation and input for the Sorong Regency government to plant the values of Kambik education itself in the generation of indigenous Moi children in Sorong Regency in particular and the Moi generation in general. The results of the study are, First: project files for alternative education design in Sorong Regency or can be synergized with a special curriculum.
\end{abstract}

\section{Keywords: Relapse Education, Participation, and Value}




\section{PENDAHULUAN}

Papua selalu menjadi tema hangat dan baik untuk diperbincangkan di masyarakat lokal, nasional dan dunia.Papua menjadi seksi dan menarik untuk disajikan, namun kali ini bukan persoalan politik, sparatisme, atau kasus papa minta jatah disalah satu perusahaan pertambangan.

Ini menjadi perenungan dalam desain dan mainstream kehidupan yang terus berdinamis dalam menjawab tantangan di Papua. Harus diakui bahwa pendidikan menjadi tubuh Negara dan dijadikan vitalitas dalam membangun suatu cita-cita Tamadun, Pendidikan hangat dibicarakan dimana-mana dan jauh lebih wibawa ketika kultur pendidikan ini dihidupkan. Gagasan dasar/fundamental karakter dalam kemerdekaan akademik itu sendiri tidak harus berada pada pendidikan yang berlevel tinggi dan bergelar Profesor, tetapi dalam kemerdekaan akademik bisa memberikan pandangan yang bisa menciptakan kedamaian jiwa atau dalam pandangan Platonisme jiwa berkolega.

Di tahun 2015 Balai Pelestarian Nilai-Nilai Budaya (BPNB) Jayapura mengusulkan tiga (3) kapung adat, (1) kampung adat Heram Ayafo Kab.Jayapura dengan ketua Lewi Puhili, (2) Kampung adat Gume Kab. Lani Jaya dengan ketua Beran Tabuni, (3) Kampung Maladofok (Lembaga Adat Kampung Maladofok) ketua Mikha Klin (sumber: kebudayaan.kemdikbud.go.id/pbnbpap ua/2015/10/12).

Dalam rumah adat moi di segala hal yang menyangkut dengan suku moi di atur seperti: (1) sistem perkawinan, (2) sistem pembagian harta, (3) sistem adat dalam mengatur perempuan moi, (4) sistem adat dalam hak ulayat tanah, (5) sistem pembayaran adat bagi yang meninggal, (6) sistem pendidikan kambik, (7) sistem bercocok tanam, (8) sistem pengobatan, (9) sistem marga dan daerah-daerah keramat.

Pendidikan Kambik (Pendidikan adat) suku Moi penguasa tanah Malamoi di kepala burung di tanah Papua.Pendidikan Kambik memiliki 
kekuatan dan etos perjuangan yang kuat, dalam sistem itu memberikan kita nilai-nilai kehidupan dan memahami alam. Tetapi menjadi menarik pendidikan kambik ini sangat dekat dengan dimensi mistisisme sebab dalam pendidikan kambik akan diberikan pengetahuan tentang pengobatan tradisional "secara mistik" ini selain hal makna hidup, mencintai alam, dan produk/lulusan dari pendidikan Kambik bisa menjadi seorang pemimpin atau kepala suku.

Ada nilai-nilai yang ditanamkan dalam pendidikan Kambik (pendidkan adat suku Moi) antara lain sebagai beriktu: Pertama: kepemimpinan (regerasi untuk bicara kepemimpinan adat). Kedua: pengobatan secara tradisonal. Ketiga: pemahaman eksistensi diri, dan Emapt: sejarah dan budaya orang Moi.

Poin dari pendidikan adat kambik ini menjadi penting untuk dimaknai dan ditunaikan dalam kehidupan sehari-hari. Dalam kesempatan ini penulis mengutip pendapatnya Ibnu Khaldun, bahwa sekolah/pendidikan itu ada dua model, pertama pendidikan diajarkan oleh para guru, ulama, professor yang dimaknai sekarang sebagai bentuk dari pendidikan formal, sedangkan yang kedua adalah pendidikan yang diajarkan oleh alam. Alam yang memberikan sumber pengetahuan manusia melalui fenomena dan bukti empirisme sehingga kita mampu menemukan kebenaran sejati.

Tak sedikit pengaruh pendidikan global yang menghantam sendi-sendi peradaban pendidikan kultur dan pendidikan kultur kembali hilang pada porsi dan posisi sebagaimana mestinya. Penting penulis melihat ini sebagai tantangan dan fenomena yang mendasar dan memiliki rentetan yang tak pernah putus. Dalam penelitian ini, peneliti mengangkat tema tentang: Partisipasi Masyarakat Moi Dalam Pelaksanaan Pendidikan Adat Kambik (Studi Kasus Tentang Kelangsungan Pendidikan Kambik Di Suku Moi Kampung Maladofok Kabupaten Sorong).

\section{KAJIAN PUSTAKA}

Pengertian Pendidikan Kambik 
Orang-orang moi itu dibagi dalam empat struktut sejak zaman batu, yaitu: (1) tokoh-tokoh adat, (2) alumni pendidikan adat kambik (wilifi), ini adalah kelompok yang telah mngikuri pendidikan adat kambik (rumah adat tempat pendidikan adat) dan telah disidudakan secara adat. Kelompok ini dibina untuk menjadi pemimpin seperti kelompok pertama, mereka diajarkan tentang filosofi kemimpinan dan adat istiadat suku moi secara lengkap. (3) kelompok lelaki (Nedla) yang dikategorikan sebagai Nelagi (perempuan), kelompok terdiri atas anak laki-laki, pemuda dan lakilaki dewasa yang belum perna mngikuti pendidikan adat kambik, sehingga dalam struktur adat Moi dikategorikan sebagai Nelagi, (4) kelompok nelagi murni, kelompok yang terdiri atas para perempuan Moi. Kelompok ini juga memiliki pemimpin dan tokoh perempuan.Mereka diajarkan berabgai ilmu pengetahuan secara adat yang sisebut dengan fulus (ilmu khusus yang dikuasai dan berkaitan dengan dengan masalah perempuan) (Yuwono, Andi K. et al. 2010: 176-177).

Pendidikan adat kambik telah dijalaskan juga oleh Stepanus Malak dan Likewati dalam buku etnografi suku Moi.

Kambik adalah sistem pendidikan adat Moi, sistem pendidikan yang menciptakan sumber daya yang bisa berefek kepada kepentingan masyarakat atau orang-orang Moi.Dalam Sejarah pendidikan suku Moi terdapat suatu pendidikan adat yang sakral yang disebut Kambik. Lulusan kambik atau pendidikan adat ini merupakan kelompok dalam struktur masyarakat adat Moi dan hanya anak laki laki (Nedla) yang berhak untuk mengikuti pendidikan adat yang telah dipilih secara adat. Dalam pendidikan Kambik ini,siswa diajarkan tentang kepemimpinan dan bidang bidang pengetahuan tertentu dan juga adat istiadat suku moi secara mendalam dan lengkap. Seperti halnya tamatan sekolah dewasa ini, dalam pendidikan adat juga diberikan gelar kelulusanya. Tamatan Pendidikan Dasar (ulibi) saat ini disebut SD (Sekolah Dasar) dalam pendidikan kambik diberikan gelar unsulu.Ini adalah gelar terendah.Ada pula Unsmas, tulukma. Gelar tingkatan berikutnya Untlan dan Kmaben yang merupakan jenjang 
tertinggi yang akan melahirkan gelar wariek atau sukmin merupakan gelar terbesar atau guru besar. Wariek menurut pernyataan seorang siswa lulusan terakhir pendidikan kambik adalah gelar yang di berikan dari daerah Tamraw karena gaum dan pengaruh pendidikan Kambik ini hingga menembus wilayah lain. Gelar-gelar ini diberikan karena telah lulus dan memiliki kompetensi terhadap bidangbidang tertentu seperti pengobatan, kesehatan, ahli meramal adat istiadat dan lain lain (Stepanus Malak dan Likewati, 2011: 24).

Lanjut, dalam buku "etnografi suku moi", Stepanus Malak dan Likewati mengulas tentang sistem pendidikan Kambik, berikut kutipannya:

Belajar dipendidikan kambik (pendidikan adat Moi) tidak ditentukan waktunya biasa 6 bulan,12 bulan dan terlama 18 bulan tergantung kemufakatan pelaksana pendidikan dan tokohtokoh adat pada waktu itu. Marga Ulimpa merupakan marga yang sejak dulu mempunyai hak untuk melaksanakan pendidikan ini. Desa atau kampung Klaben di distrik Moraid merupakan tempat penyelenggaraan Kambik sebagai pusat pendidikan sejak awal pendidikan ini ada hingga berakhir pendidikan dan tidak diadakan lagi pendidikan adat di kampung Klaben ini pada akhir tahun 1943 sejak perang dunia II. Sebelum masuknya kesultanan Tidore diperkirakan pendidikan adat ini telah ada.Tidak adat data yang tertulis tentang kapan dimulainya pendidikan adat ini (Stepanus Malak dan Likewati, 2011).

Dalam penjelasan tersebut diatas bisa diberikan suatu simbullan bahwa sistem pendidikan Kambik suku Moi cukup sistematis dan tertata dengan mekanisme kurikulum yang cukup ketat. Sebab pendidikan Kambik memiliki etik yang tidak begitu saja orang-orang bergabung dan mengikuti proses ini, selain itu juga seorang perempuan tidak terlalu menjadi prioritas dari pendidikan kambik itu sendiri. 


\section{\begin{tabular}{ll|l} 
Jurnal Noken, Volume 4 (1) Halaman 87-106 & 2018
\end{tabular}}

Dalam tulisan Andreas

Dedawartawan cahaya Papua yang kemudian di kutip oleh kompasiana. Berikut pendapat Andreas Deda: Program pendidikan dalam ',Kambik' dilakukan untuk mengajar para siswanya agar bisa memahami alam dan bisa berkomunikasi dengan alam secara magis.Banyak kaum pria dari Suku Killis yang belajar di lembaga pendidikan adat „Kambik ${ }^{e e}$ dan memang kaum pria yang diutamakan. Bagi Suku Killis, seorang pria dianggap sebagai laki-laki seutuhnya jika ia sudah lulus dari lembaga

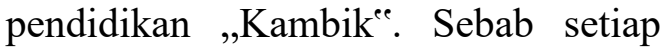
pria yang sudah lulus dari lembaga pendidikan ini dipastikan ia sudah benar-benar memahami lingkungan dan bisa berkomunikasi dengan lingkungannya. (sumber: : http://www.kompasiana.com,) di akses 29 april 2017.

\section{Pendidikan Kultur/tradisional}

Hakekat pendidikan secara sederhana di artikulasikan sebagai upaya manusia untuk membina kepribadiannya sesuai dengan nilai- nilai di dalam masyarakat dan kebudayaannya. Tafsir lain pendidikan adalah prose untuk mengelola potensi dan menjadi kompetensi dan bisa berdaya saing dan mampu mengamali kualitas kepribadian, budi baik yang tidak bertentangan dengan nilai. Nilai ini yang harus disimak secara baik sebuah nilai pendidikan itu sendiri yang tidak merugikan dan tidak bertentangan dengan kehidupan bermasayarakat.

Mengutip pendapat $\mathrm{Ki}$ Hajar Dewantara,bahwa pendidikan sebagai upaya untuk memajukan budi pekerti, pikiran serta jasmani anak, agar dapat memajukan kesempurnaan hidup dan menghidupkan anak yang selaras dengan alam dan masyarakatnya.

Pendidikan bagian dari pada pembangunan identitas nasional bukan hanya terjadi di dalam lingkungan sisitem pendidikan formal, tetapi juga di dalam keluarga dan masyarakat. Bahkan pengaruh yang diberikan oleh keluarga dan masyarakat akan memberikan efek yang sangat mendalam terhadap pembentukan kepribadian nasional dari pada oleh 
sistem formal (H.A.R Tilaar, 2007: 156-157).

Menyinggung masalah pendidikan transformasi penting penulis mengutip pendapat dari Paul Freire (1921-1997), pendidikan untuk membebaskan berbagai jenis tekanan dari luar. Untuk membebaskan berbagai jenis ikatan dan tekanan ialah perlu adanya kesadaran dari setiap manusiaadakan kebebasannya. Proses penyadaran terhadap otonomi individu adalah inti dari pedagogic Freire (H.A.R Tilaar, 2007)

\section{Partisipasi Masyarakat}

Harapan untuk membangun
manusia yang berkualitas, harus
berpartisipasi.Partisipasi jika dimaknai
adalah hal yang mudah dan
membutuhkan sedikit kesempatan
untuk menyertakan diri pada sebuah
kegiatan atau event. Penulis mengutip
pendapat Made Pidarta dalam Siti
Irene Astuti D. (2009: 31-32),
partisipasi adalah pelibatan seseorang
atau beberapa orang dalam suatu
kegiatan.Keterlibatan dapat berupa
keterlibatan mental dan emosi serta

fisik dalam menggunakan segala kemampuan yang dimilikinya (berinisiatif) dalam segala kegiatan yang dilaksanakan serta mendukung pencapaian tujuan dan tanggungjawab atas segala keterlibatan.

Dalam penjelasan, kita bisa simpulkan bahwa dalam dunia partisipasi adalah keterlibatan langsung dalam sebuah agenda atau acara yang telah berlangsung.Konteks ini penulis ingin sampaikan bahwa, dalam penelitian ini kita ingin membaca partisipasi dari masyarakat adat Moi dalam pendidikan Kambik/pendidikan adat. Dalam kepentingan global yang semakin mengkompleks dan telah tergusur dengan modernitas yang luar biasa pengaruh dan bahkan pendidikan Kultur terjepit dan bahkan tak berdaya.

\section{Konsep Nilai}

Pandangan filsafat tentang konsep nilai masuk pada ranah kajian filsafat axsiologi.Makna sederhana yang dipahami tentang nilai yang gambarkan oleh Ali Modhofir (1996:21), bahwa perbuatan manusia 


\section{\begin{tabular}{ll|l} 
Jurnal Noken, Volume 4 (1) Halaman 87-106 & 2018 \\
\hline
\end{tabular}}

benarnya harus bergantung pada pertimbangan tentang nilai atau kebaikan dari sesuatu hal, misalnya tindakan, motif, akibat-akibat baik yang nyata.

Penjelasan tersebut diatas menunjukkan bahwa setiap aktifitas manusia memiliki standar yang diresapi dengan sistem nilai. Sehingga sikap kehati-hatian dan membuat orang tersingung adalah sikap yang terikat dengan sistem nilai sosial yang dimiliki orang lain.

Selanjutnya bicara masalah nilai di bicarakan oleh Loren Bagus (2005: 713), nilai itu berasal dari kata latinvalere(berguna, mampu akan, berdaya, berlaku dan kuat). Lanjutnya dia katakan bahwa teori nilai adalah pandangan dalam estetika dan etika bahwa:

(1) Nilai-nilai ada di dunia luar terlepas dan terlepas diluar dari pemahaman (penangkapan) kita tentangnya;

(2) Nilai-nilai itu dapat ditemukan dan dikenali;
(3) Nilai-nilai itu harus digunakan sebagai prinsip bagi penilaian dan perilaku;

(4) Objek atau kegiatan bernilai karena kualitas yang ada secara objektif di dalam nilai itu, yang jika dipersepsi, dirasa, atau dialami, membuat nilai itu diterima (dianjurkan).

\section{MOTODE PENELITIAN}

Penelitian ini menggunakan metode deskriptif kulitatif, dengan pendekatan studi kasus tertentu yang menelaah sebuah studi kasus kasus dalam kehidupan masyarakat.

1. Teknik Pengumpulan Data

Untuk penelitian ini mengumpulkan data sebagimana dijabarkan sebagai berikut:

a. Observasi non-Partisipasi

Obsevasi non-partisipasi, yaitu jenis metode observasi, di mana seorang peneliti berperan sebagai "penonton" saja tidak terjun secara langsung sebagaiman observasi partisipasi.Jadi ketika mengamati kelompok yang menjadi subjek penelitian, peneliti seolah menjaga 
jarak, tidak terjun langsung berbaur dengan kelompok penelitiannya.

b. Wawancara

Wawancara, yaitu teknik pengumpulan data dengan melakukan wawancara secara mendalam dan langsung. Dalam wawancara akan melahirkan interaksi antar kedua belapihak atau lebih. Dalam melakukan wawancara tentunya pada sasaran dan orang yang paham dan pernah mengikuti kegiatan pendidikan kambik di maladofok.

c. Teknik Dokumentasi

Menurut Suharsimi Arikunto (2010 :274) Mengemukakan: "Metode Dokumentasi Yaitu Mencari Data Mengenai Hal-Hal Atau Variabel Yang Berupa Catatan, Buku, Surat Kabar,”. Hubungannya Dengan Penelitian mengenai pendidikan kambik/pendidikan adat masyarakat moi.

\section{Teknik Analisis Data}

$\begin{array}{rrr}\text { Selanjutnya } & \text { dari } & \text { jenis } \\ \text { penelitian diatas } & \text { maka } & \text { peneliti }\end{array}$
menggunakan model interaktif dari Miles dan Huberman, (2014:14)untuk menganalisis

data

hasil
penelitian.Adapun model interaktif di jelaskan berikut ini:

a. Reduksi data (Data Reduction),

Data yang dimiliki peneliti di lapangan melalui wawancara, observasi dan dokumentasi direduksi dengan cara merangkum, menyeleksi dan memfokuskan data Pengumpulan data Penyajian data Reduksi data Kesimpulankesimpulan Penarikan /verifikasi pada hal-hal yang sesuai dengan tujuan penelitian. Pada tahap ini, peneliti melakukan reduksi data dengan cara memilah-milah, mengkategorikan dan membuat abstraksi dari catatan lapangan, wawancara dan dokumentasi.

b. Penyajian Data (Data Display)

Penyajian data dilakukan setelah data selesai direduksi atau dirangkum. Data yang diperoleh dari hasil observasi, wawancara dan dokumentasi dianalisis kemudian disajikan dalam bentuk keterangan Wawancara), kerangan Lapangan) dan ketrangan Dokumentasi. Keterangan data ini untuk mempermudah penelitin dan menganalisa data. 


\section{PEMBAHASAN}

Model Partisipasi Masyarakat Moi dalam Pendidikan Adat Kambik Pelaksanaan Pendidikan Adat Kambik

Sebelunya kami sampaikan bahwa tingkat partisipasi pendidikan adat kambik saat ini tidak sebanding dengan lajunya pertumbuhan masyarakat suku Moi. Memang ada kehawatiran, bahwa rendahnya tingkat partisipasi masyarakat dalam pendidikan adat kambik, memberikan satu efek dekadensi nilai-nilai yang terkandung dalam pendidikan adat kambik. Tapi satu alasan yang mendasar yang selalu dijadikan rujukan dalam sistem pendidikan adat kambik adalah peserta yang ikut dalam pendidikan adat kambik adalah orangorang yang terseleksi sebelumnya dan dianggap layak untuk mengikuti pendidikan adat kambik.

Pendidikan adat kambik dilaksanakan dengan rencana yang sangat matang. Berdasarkan hasil analisis, perencanaan dalam pendidikan adat Kambik memperhitungkan semua kebutuhan selama diadakan pendidikan adat kurang lebih enam bulan. Hal ini menunjukkan suku Moi memiliki perhitungan yang sangat cermat. Pelaksanaan pendidikan adat Kambik dibagi menjadi tiga tahap persiapan, tahap pelaksanaan dan tahap penutupan. Seluruh peserta yang akan mengikuti pendidikan kambik harus terlebih dahulu mengikuti orentasi awal hingga perserta tersebu pantas dan layak untuk mengikuti proses penddidikan adat kambik.

Dalam tahapan pendidikan adat kambik, Bapak Ulim menjelaskan bahwa:

Pendidikan adat kambik masyarakat Moi, bukan seseuatu hal yang gampang dan muda. Dari proses pendidikan harus dilewati dengan proses penjaraingan yang ketat seghingga orang-orang yang terlibat dalam pendidikan adat kambik betulbetul memiliki hasil yang bagus. Sebab kemampuan orang-orang yang lulus dari pendidikan adat kambik harus menguasai bebrapa kemampuan, baik itu obat tradisonal, sistem kemimpinan, memahami konsep diri, 


\section{Jurnal Noken, Volume 4 (1) Halaman 87-106 2018}

sejarah, dan sosial budaya. Oleh karena itu substansi dari partisipasia masyarakat dari Moi dalam pendidikan adat kambik harus mengikuti proses dari awal hingga akhir. (Hasil Wawancara dengan Bapak Ulim).

Dari hasil wawancara dengan informan tersebut, bisa kita lihat temuan yang dilakukan oleh Stepanus Malak dan Wa Ode Likewati (2011:134), pendidikan adat kamik adalah salah satu pendidikan sakaral dalam masyarakat adat Moi. Dalam pendidikan adat kambik hanyalah ada di struktur masyarakat adat Moi dan hanya diperbolekhakan untuk anak laki-laki (nedla), hanya nedal-lah yang memiliki hak dan proses pertasipasinya harus dipilih oleh adat.

Tasfir kitas atas pendidikan adat kambik itu sendiri adalah satu tradisi pengetahuan yang hanya mengedepankan untuk golongan lelaki. Karena satu alasan kelompok lelaki adalah mereka sebagai pengendali dan pewaris dari apa yang menjadi persan dari masayarakat ada Moi. Jika disimak keterbatasaan laki-laki dalam pendidikan adat kambik adalah bagian dari pada bisa pengkotomian atau pengaruh kuatnya tradisi paternalism. Sedangkan di alasan lain bisa kita lihat pendapatnya Silas Kalami, bahwa yang layak partisipasi adalah keturunan anak laki-laki atau nedla. Sebab anak perempuan disatu saat naiti dia menika dan berkepergian megingikuti adat suaminya.

Semangat partisipasi dalam proses pendidikan adat kambik di masayarakat Moi terjadi diseluruh elemen. Kareana dalam pendidikan kambik selain mempersiapkan mental oleh peserta, para keluarga dan masyarakat mempersiapkan baik secara logistik dan kebutuhan lainya untuk semua terpenuhi dalam mengikuti proses pendidikan adat kambik. Betapa pentingnya partispasi masyarakat, sebagaimana diungkap oleh Made Pidarta dalam Siti Irene Astuti D, bahwa partisipasi adalah pelibatan seseorang atau beberapa orang dalam suatu kegiatan. Keterlibatan dapat berupa keterlibatan mental dan emosi serta fisik dalam menggunakan segala kemampuan yang dimilikinya (berinisiatif) dalam segala 


\section{Jurnal Noken, Volume 4 (1) Halaman 87-106 2018}

kegiatan yang dilaksanakan serta mendukung pencapaian tujuan dan tanggungjawab atas segala keterlibata.

Dari hasil riset yang dilakukan oleh peneliti menemukan bahwa mental partisipasi dalam pendidikan kambik itu cukup tinggi karena, dalam berlangsunya pendidikan adat kambik semua masyarakat adat mendukung penuh seluruh kegiatan, mereka menyediakaan bahan makanan sebelum jauh-jauh hari. maka dari itu masyarakat adat Moi memiliki tahapan yang cukup matang mulai dari persiapan-pelaksanaan dan evaluasi demi keberlangsungannya pendidikan adat kambik.

Partisipasi pendidikan adat kambik harus dari seluru elemen, yang terpenting adalah komponen murit dan pengajar. Partisipasi pendidikan adat kambik harus sesuai dengan tapan-tahapanya. Dalam struktur budaya masyarakat Moi tahapan itu telah digambarkan dalam dari perencanaan hingga evaluasi (pengujian) dan kemudian bisa memberkan gelar dan oleh guru dan dewan adat.
Pertama, Tahap persiapan dalam pendidikan adat Kambik adalah menyiapkan semua kebutuhan selama penyelenggaraan pendidikan adat, yaitu kurang lebih selama enam bulan atau dua belas bulan (1 tahun). Mulai dari persiapan tempat dan kesediaan bahan makanan yang cukup, menyiapkan pengajar. untuk menentukan seorang ulibi (murit) itu sudah sudah dilaksanakan sebelumnya yang disebut dengan pra-orentasi. Praorentasi setiap calon ulibi diseleksi kemudian mengikuti proses yang panjang hingga dia layak dan pantas untuk mengikuti dalam pendidikan adat kambik. Hasil riset yang dilakukan oleh Suntoko menegaskan bahwa dalam pendidikan adat kambik membutukan orang-orang partisipan yang bijak dan arif karena untuk mengurusu begitu banyak peserta dan instrum yang lain.

Kedua, Tahap pelaksanaan pendidikan Kambik dibagi menjadi tiga bagian, yaitu pembukaan, pelaksanaan pendidikan, dan ujian. Hal ini sesuai dengan perencanaan setiap kegiatan pada umumnya, yaitu 


\section{Jurnal Noken, Volume 4 (1) Halaman 87-106 2018}

kegiatan pembukaan, kegiatan inti, dan uji keberhasilan, pembukaan dalam pendidikan adat Kambik mempertunjukkan keahlian para gelebe dan fince terhadap ilmu yang dikuasai. Pertunjukan tersebut bertujuan untuk menguji kekuatan ilmu yang akan diajarkan pada para ulibi. Selain itu, diadakan peresmian pelaksanaan pendidikan adat, mengajak para orang tua turut serta mengawasi dan mendukung anaknya dalam pendidikan adat Kambik. Artinya dalam pembukaan tersebut telah terjalin kerjasama antara penyelenggara pendidikan dengan orang tua ulibi, (Suntoko, 2012: 19). Partispasi dalam tahapan ditegaskan oleh Silas Kalami Ketua LMA Malamoi, bahwa pelaksanaan pendidikan adat kambik ini adalah tahapan yang sangat penting dan fundamental, sebab dari sekian tahapan yang ada para ulibi harus mengikuti dengan baik karena ini menjadi syarat untuk melanjutkan pada tahpan berikutinya dalam ujian. Para peserta ulili harus taat pada aturan yang telah menjadi dasar kesepakatan dan dikawal oleh karena itu para fince dan usmas. Pengawasan untuk menjaga kesaralan dan kesempurnaannya pendidikan adat kambik mendapat partisipasi langsung dari kmakbe, kemudian kamakbe memberkan laporan dan evaluasinya perkembangan pelaksanaan pendidikan adat kambik kepada gelebe/pengajar (Hasil Wawacanra Dengan Bapak Silas Kalami, Ketua Dewan Adat LMA Malamoi)

Ketiga, tahap evaluasi. Rangkayan dari awal hingg ahir adalah ujian, ujian menjadi salah satu barometer untuk mengukur kemampuan dari seorang ulibi. Sasaran utama dari ujian itu sendiri adalah mengukur kemampuan dalam penguasaan materi dan ilmu yang telah diberikan oleh pendidik. Sistem yang dibangun dalam pendidikan adat kambik masyarakat Moi, memiliki hasil yang baik karena menggunakan tahapan dari awal sampai pada evaluasi yang dinamakan ujian, sebagaimana dikenal dalam pendidikan modern. Suntoko, (2012:20) katakan bahwa evaluasi 


\section{\begin{tabular}{|l|l|} 
Jurnal Noken, Volume 4 (1) Halaman 87-106 & 2018 \\
\hline
\end{tabular}}

dalam pendidikan adat kambik adalah ujian, sebab ujian tersebut merupakan wujud tanggung jawab terhadap keberhasilan pendidikan adat kambik sesuai dengan tujuannya, yaitu menciptakan kepemimpinan yang sesuai dengan harapan masyarakat dan menciptakan suatu keahlian bagi untelen. Pelakasanaan ujian diselenggarakan oleh para fince dan usmas dan dibawah tanggung jawab para gelebe. Dalam pendidikan adat Kambik penutupan diselenggarakan dalam rumah kambik besar. Acara dalam penutupan adalah penganugrahan gelar bagi para untelen, pemeberian tanda (pendidikan ditelinga) bagi para untelen, dan saling memaafkan antara pantia penyelenggara kepada para orang tua untelen, dan di akhiri dengan penyerahan kembali untelen kepada orang tua yang dilakukan oleh gelebe. Gambaran tersebut menunjukkan bahwa pendidikan adat Kambik suku Moi sudah mempunyai organisasi pendidikan yang baik dan maju dalam keberadaban manusia sejak dahulu.
Dalam tahapan ujian itu sendiri, Bapak Ulim, katakan bahwa penguasaan ilmu itu bisa menembus unsur yang adalah dalam alam semesta ini. Dalam arti kemampuan dalam imunya bisa menembus alam realitas. Misalkan dia bisa menajdi darah, atau bisa menjadi air. Keprcayaan terhadap pengatahuan dimiliki memiliki standar mistik. Sedangkan di sisi penelitia cermati dari hasil wawancara dengan bapak Silas Kalami, bahwa pendidikan adat kambik adalah satu-satunya cara orang untuk memahami siapa dirinya dan bagaimana dia bermanfat untuk masyarakat Moi itu sendiri.

Peneliti menemukan dua alasan dalam kenapa proses pendidikan adat kambik hingga kini tidak dilaksanakan lagi. Pertma, kehadiran Negara yang terlalu agresif melihat kumpulan dan kelompok komunitas sebagai gerakangerakan sparatisme. Kecurigaan negar memberikan satu efek sehingga pendidikan adat kambil lambat laun hilang. Kedua, kehadiran agama memberian satu ketegasaan bahwa pendidikan adat kambik adalah tradisi yang sirik dan dilarang dalam agama. 
Factor kedua ini juga dikatakan oleh Stepanus Malak dan Wa Ode Likewati dalam buku etnografi suku Moi.

\section{Penanaman Nilai-Nilai Pendidikan Adat Kambik dalam Kehidupan Masyarakat Moi.}

Nilai-nilai yang terkandung dalam pendidikan adat kambik begitu banyak dan behubungan dengan dimensi hidup manusia. Dasar dan orentasi dari pendidikan adat kambik pada memahami konsep diri, sistem kemimpinan, pengobatana tradisonal dan sejarah dan sosial-budaya. Poin ini yang menjadi dasar dalam proses pendidikan adat kambik masyarakat Moi. Ungkapan dari Josias Kamuru, bahwa nilai yang terkandung dalam pendidikan adat kambik adalah nilai kehidupan, kemanusian dan kematian karena puncang dari keyakinan masyarakat Moi sebelum masuknya agama adalah mereka percaya pada Fun Abalyut (Tuhan yang kekal).

Tapi pendapat tersebut di atas masih jauh dari nilai praktis dalam sosial bermasyarakat. Pendidikan adat kambik memiliki pandangan kefilsafatan yang kuat dan hal itu akan bicara pada tahapan epistemic, aksiologi dan ontologisme. Ketiga dimensi kefilasafata itu terlihat jelas dalam nilai-nilai yang terkandung dalam pendidikan adat kambik.

Pertama, Nilai religi dan kearifan. Masyarakat Moi dalam sejarah peradaban manusia memiliki kepercayaan kuno sebelum masinya agama. Tetapi meraka memiliki dasar dan prinsip keyakinan pada kekuataan alam semesta dan itu adalah bagian dari pada ketahuidan dalam meyakini sesuatu yang maha besar. Nilai religi terlihat pada kepercayaan mereka kepada fun abalyut yaitu percaya terhadapa kekekalan terhadap Tuhanm tunggal yang memiliki kekekalan. Selain itu mereka juga percaya terhadap fun nah dan muwe yang dianggap hidup didunia lain. Fun nah dan muwe yang dipercaya mendimi tempat-tempat yang dikeramatkan. Kepercayaan tersebut seperti percaya pada pohon besar, batu, dan bendabenda yang dianggap mempunyai kekuatan. Masyarakat Moi begitu percaya atas kekuataan gaib dan mitis, 
walau sebagian cerita itu dipandang oleh manusia modern adalah mitologi semata. Cosmologi kepercayaan meraka masih sangat tergantung pada alam atau yang dikenal sebagai Fun Abalyut.

\section{Kedua,}

Nilai

pagyuban/kekeluargaan dalam pendidikan adat Kambik terlihat dalam kegiatan pelaksanaan pendidikan adat. Dalam rumah Kambik behitu solit dan kompak dalam proses pendidikan adat kambik, memulai dari tahapan perrencanaan hingga pada akhir. Keluarga hadir untuk dari berabgai penjuru dan gelet yang ada, kemudian terhimpun dalam satu rumah kebersamaan yang disebut dengan rumah Kambik. Membangun basis paguyuban/kekeluargaan yang kuat, maka dari itu lahirnya spirit gotongroyong. Proses pendidikan kambik berjalan seluruh keluarga berkumpu dan memberkan dukungan dan persiapan persediaan sebagai bentuk dari kerjasama yang baik demia kelancarana kegiatan. Hasil riset dari Suntoko, (2012), menggambarkan bahwa: "Hubungan kekeluargan atau kekerabatan. Setelah pelaksanaan pendidikan adat Kambik, terdapat pranata hubungan kekerabatan yang terlihat dalam kehidupan bermasyarakat melalui hubungan msan yaitu hubungan antara keret yang satu dengan keret yang lain, hubungan tamtlok yaitu hubungan kekeluargaan antara individu yang satu dengan yang lainnya, hubungan tambik yaitu hubungan pertemanan, hubungan tanmah yaitu hubungan dengan rekan kerja, dan hubungan simin yaitu hubungan kekeluargaan dan kekerabatan melalui perkawinan.

Ketiga, Nilai solidaritas dan gotongroyong. Dalam pendidikan adat Kambik di masyarakat Moi menkonstruksikan satu paradigm bahwa betapa pentingnya hidup berdampingan sebagai manusia, karena itu terjadi simbiosis antra individu satu dengan yang lain. Mengedepankan nilai-nilai kebersamaan dan kemanusiaan itu semua karena dasar saling memahami tugas dan perannya masing-masing. Penghormatan dan saling menghargai menjadi kunci, hal 
itu salah satu poin penting yang selalu diutamakan oleh masyarakat adat Moi. Stepanus Malak, mengungkapa bahwa "Orang-orang Moi begitu lembut dalam bertutur kata, terlebih lagi mereka mencitai kedamain dan saling menghormati persaudaraan. Hal itu semua bahwa sengat itu terilhami dalam pemikiran orang-orang Moi begitu terbuka dalam organisasi sosial yang hubungan kekerabatan, relasi kemargaan yang kuat dan terbuka terhadap pendatang."

Keempat, Estetika atau nilai keindahan telah diajarkan dalam proses pendidikan adat kambik. Proses pendidikan berjalan akses dan imajinasi dimainkan dalam membentuk satu nilai seni yang tinggi, perserta bernyanyi bertabur alat tradisonal dengan nada dan bahasa kunu dari Moi. Senia menjadi bagian dalam mendorong kemampuan para ulibi untuk terus menemukan bentuk imajinasinya, tak sekedar itu nyanyiannyanyian itu bisa memberikan efek sosial pada masayarakat ada moi karena dalam nyantian itu mengandung pesan moral dan kearifan yang tinggi.

Nilai seni baik itu lagu, salimua dan bahkan ukurian selalu dilantunkan dan tampilkan setiap saat. Nilai penting dalam pendidikan adat kambik adalah bagaiman mereka menyampaikan ilmu/transfer pengatahuan yang dimiliki oleh pendidik kepada ulibi dengan metode dan strategi pembelajaraan yang mereka meliki. Orang-orang Moi memiliki senia berilmu yang baik dalam peradabanya, sebab dalam pembelajaran yang baik dan berhasil adalah tergantung pada seni menyampaikan ilmu pengetahuan itu sendiri.

Kelima, Nilai Ekonomi. Pendidiam pendidikan adat Kambik terdapat nilai-nilai ekonomi dari tahap awal perencanaan, tahap persiapan, tahap pelaksaaan sampai pada kembalinya para untelen dimasyarakat. Pada tahap perencanaan nilai ekonomi terlihat saat merencanakan tempat yang akan digunakan. Ditempat pelaksanaan pendidikan adata kambik harus terdapat lumbung pangan dan air 


\section{\begin{tabular}{|l|l|} 
Jurnal Noken, Volume 4 (1) Halaman 87-106 & 2018 \\
\hline
\end{tabular}}

cukup yaitu dekat hutan sagu dan di wilayah yang tekstur tanahnya subur untuk ditanami umbi-umbian. Pada tahap persiapan nilai ekinomi terlihat pada cara menyiapakan persediaan pangan ribuan orang selama kurang lebih enam bulan pelaksanaan pendidikan adat, (Suntoko,2012). Nilai ekonomi ini terlihat jelas dalam semangat masyarakat yang terlibt langsung dalam mempersiapkan persedian pangan itu sendiri. Etos kerjasama tidak terlepas dari nilai yang meraka banguan sebab orang-orang Moi lembih banyak mengihlaskan hak kemilikannya untuk kepentingan bersama atau yang dikenal dalam filsadat sosial sebagai altruism. Nilai ekonomi yang dibanguan bukan nilai ekonomi yang bersifat individualis tetapi nilai ekonomi kolektif.

Keenam, Nilai Pendidikan Politik menjadi penting, sebab dalam pendidikan adat kambik sendiri mendidik para ulibi yang setelah lulus dipersiapakan menjadi pemimpin masa depan. Pendidikan kambik mengajari tentang sistem kemimpinan dan bagaimana ketaatan pada nilai, lembaga, pranata-pranata, normanorma, dan hokum. Dalam pendidikan adat Kambik mengharapkan menglahirkan pemimpin yang mengutamakan kemampuan sesorang. Menurut Sontoko dalam hasil risetnya dia menganggap bahwa orang-orang Moi menghendaki sistem demokrasi sebab rujukan pemimpin lebih pada kulitas dan pendidikanya.

Dalam kontes ini sebagai penelitia sedikit berbeda dengan Sontoko, sebab temuan yang dilakukan oleh peneliti dari dukumen dan temuan lapangan bahwa orang-orang Moi dalam mendorong seorang pemimpin dari hasil musyawarah mufak seusia dengan kultur ketimuran. Hal ini dipertegas oleh B. Wahid dalam penelitian modal sosial dan kepentingan elit politik dalam pemilihan pemimpin lokal di kabupaten sorong. Temuannya menggambarkan bahwa orang-orang Moi memberikan pemahaman politik pada masyarakat adat dengan berserah pada keputusan dewan ada di Maladofok. Keputusan adat adalah hasil dari keinginan masyarakat adat 


\section{Jurnal Noken, Volume 4 (1) Halaman 87-106 2018}

Moi secara kolektif. Nilai pendidikan politik yang ditanamkan dalam pendidikan adat kambik adalah sosok pemimpin yang tepat adalah orangorang yang memiliki kemampuan dan pria berwibawa yang taat pada norma dan adat.

Ketujua, Nilai Edukasi. Arah dari pendidikan adat kambik hubungan praktisnya dengan kecerdasan dan mental generasi. Narasi dalam dunia pendidikan memberikan efek besar terhadap perubahan pandangan dan cara berfikir. Walau bebrapa catatan dalam pendidikan kambik itu sendiri tidak memberkan ruang pada anakanak perempuan karean alasan yang mendasar tentang adat. Tetapi nilai edukasi yang bangun oleh pendidikan ada kambik memberikan ruang pengetahuan dan keadaban orangorang Moi. Pertama Kepentingan pendidikan adat kambik sebagai pembekanal ilmu untuk generasi, membanguan mental mempersiapkan diri menghadapai perubahan zaman, mengarahkan potensi yang dimiliki, dan kemasaan atau keberhasilan yang dicapai adalah diperjuangkan dengan sungguh-sungguh dengan tahapan yang dilewati.

\section{KESIMPULAN}

Hasil penelitian dilakukan di kampung Maladofo distrik Sayosa Kabupaten Sorong.

1. Semangat pertisipasi dalam pendidikan adat kambik di masyarakat Moi adalah salah satu kunici keberhasilan. Terutama dari tahpan perencanaan hingga selesainya pendidikan adat kambik yang ditandai dengan ujian kemampuan guru oleh ulibi.

2. Spirit dan substansi dari pendidikana adat kambik sampai saat ini masi ada dalam kehidupan masyarakat adat Moi. Tapi dengan hehadiran Negara dan agama membeirkan persepsi yang tidak baik dan dianggap sebagai kelompok sparatisme, dan dilarang oleh agama.

3. Nilai-nilai yang dibanguan dalam pendidikan adat kambik memberkan efek kemanusiaan terutama masyarakat Moi. Nilai itu sendiri mengajari meraka 
tentang betapa pentingnya mereka

berhidup dengan ilmu dan

wawasan.

\section{DAFTAR PUSTAKA}

A, Yuliana. Kemerdekaan Akademik Dan Pendidikan Kambik: (Membaca Suku Moi Dalam Setingan Alam Pikir). www.detikawanua.com/2016/03/ opini-kemerdekaan-akademikdan.html?m=1 (di akses pada tanggal 1 Mei 2017).

Arikunto, Suharsimi. 2010. Prosedur Penelitian. Jakarta: Rineka Ilmu Susance Ulimpa.2015.AdatIstiadat Suku Moi Dari Masa Ke Masa.(http://indonesiaartikeltau. blogspot.co.id). Diakses pada tanggal, 25 April 2016 pukul 11.23 WIT).

Astuti D, Siti Irene. 2009. Desentralisasi dan Partisipasi Masyarakat dalam Pendidikan. Yogyakarta: Pustaka Pelajar.

Bagus, Lorens. 2005. Kamus Filsafat. Jakarta: Gramedia

Malak, Stepanus \& Likewati, Wa Ode. 2011. Etnografi Suku Moi Kabupaten Sorong, Papua Barat. Bogor: Ilmiah Popular.

-----------. 2011. Kamus Bahasa Moi. Bogor: Ilmiah Popular.

Modhofir, Ali. 1996. Kamus Teori dan Aliran dalam Filsafat dan Teologi. Yogyakarta: UGM Press. Andreas Deda. (http://www.kompasiana.com).

Di akses 29 april 2017.

Saeng, Valentinus. 2012. Hebbert Marcuse, Perang Semesta Melawan Kapitalisme Global. Jakarta: Gramedia.

Suntoko. 2012. Pendidikan adat kambik: kajian nilai-nilai budaya dan model pelestarian pada masyarakat suku moi kabupaten sorong provinsi papua barat. (Tesis), Universitas Pendidikan Indonesia.

Tilaar, H.A.R. 2007. Mengindonesia Etnisitas dan Identitas Bangsa Indonesia. Jakarta: Rineka Cipta.

Wahid, Bustamin. 2016. Settingan Peradaban Ke-Indonesiaan;Membangun Papua Untuk Indonesia Dalam Perspektif Pendidikan adat Kambik. (Makalah Presentasi di forum LK 2 HMI Cab.Sorong).

Wahid, Bustamin. 2018. Peran Modal Sosial Dalam Kepentingan Elite Politik Di Pemilihan Pemimpin Lokal Di Kab. Sorong. (artikel ilmih).

Sumber Lain:

1. (sumber:

http://www.kompasiana.com,) di akses 29 april 2017. 